\title{
OS LUGARES DA INFÂNCIA NA FAVELA: DA BRINCADEIRA À PARTICIPAÇÃO
}

\author{
LOS LUGARES DE LA INFANCIA EN LA FAVELA: DEL JUEGO A LA \\ PARTICIPACIÓN \\ CHILDHOOD PLACES IN THE 'FAVELA': FROM PLAY TO \\ PARTICIPATION
}

http://dx.doi.org/10.1590/1807-03102015v27n3p494

Beatriz Corsino Pérez e Marina Dantas Jardim

Universidade Federal do Rio de Janeiro. Rio de Janeiro/RJ, Brasil

\section{RESUMO}

Buscando compreender como as crianças se apropriam dos espaços, identificando-se e agindo neles, foram realizadas oficinas com 35 crianças, de 5 a 10 anos, moradoras da Babilônia, uma favela do Rio de Janeiro. Diferentemente das crianças que possuem uma experiência mais restrita aos espaços privados, meninos e meninas dessa favela circulavam e brincavam fora de casa, com seus pares, em espaços comuns. Com isso, eles passavam a conhecer o lugar onde moram; os seus aspectos positivos, assim como os seus problemas. As crianças criticaram os transtornos gerados pelas obras do programa Morar Carioca, a má preservação dos espaços públicos, o lixo, a precariedade das moradias, entre outros. Através da ação e brincadeira, elas transformavam espaços em lugares de afeto, o que proporcionava um olhar complexo para a sua realidade e criava novos caminhos para a participação social.

Palavras-chave: infância; favela; brincadeira; participação; espaço público.

\section{RESUMEN}

Con el fin de entender cómo los niños se apropian de los espacios, se identifican y actúan sobre ellos, se realizaron actividades con 35 niños, 5-10 años viviendo en Babilonia, una favela en Río de Janeiro. A diferencia de los niños que tienen una experiencia más limitada a espacios privados, niños y niñas de esta favela circulan y juegan al aire libre con sus compañeros en los espacios públicos. Con esto, llegan a conocer el lugar en el que viven; sus aspectos positivos, así como sus problemas. Los niños criticaron los trastornos generados por las obras de Morar Carioca, la mala conservación de los espacios públicos, la basura, la precariedad de la vivienda, entre otros. A través de la acción y el juego, transforman los espacios en lugares afectivos, que proporcionaron una mirada compleja en su realidad y crean nuevas vías para la participación social.

Palabras clave: infancia; favela; jugar; participación; espacio público.

\begin{abstract}
Seeking to understand how children appropriate spaces, identify themselves and act within them, workshops were conducted with 35 children, 5 to 10 years old, living in Babilônia, a favela in Rio de Janeiro. Unlike children whose experience is more restricted to private spaces, the children of this favela went about and played outside the home, with their peers, in common spaces. In doing so, they were exposed to the problems of the place where they lived. They criticized the disturbances caused by the Morar Carioca program construction work, the poor upkeep of public spaces, the garbage, and the precariousness of the residences. Through action and play, the children transformed spaces into places they cared about, which made for a complex look at their reality, enabling them for social participation.
\end{abstract}

Keywords: childhood; favela; play; participation; public space. 


\section{Introdução}

A cidade do Rio de Janeiro é marcada por uma forte fragmentação e segregação social, possuindo áreas mais ou menos valorizadas conforme a presença de investimentos públicos e do capital privado. Tais diferenças produzem contradições no espaço da cidade que se refletem no modo de vida de seus moradores. $\mathrm{O}$ espaço da favela, habitado pelas camadas populares, é visto pelos setores dominantes como o lugar da falta dos bens materiais e simbólicos da sociedade e pela estigmatização da sua população, tomada como marginal e perigosa. As práticas culturais e as estratégias que foram construídas pelos moradores das favelas para suprir as lacunas na oferta de direitos fundamentais por parte do Estado, muitas vezes, não são reconhecidas socialmente.

A infância das camadas populares foi retratada pela Psicologia, pelas teorias da "carência" ou "deficiência" cultural (Gouvea, 1993; Patto, 1983), que desqualificam as especificidades de suas experiências de vida. Nessas teorias, que tiveram seu auge nos anos 1970, as crianças moradoras de favelas e periferias são avaliadas de acordo com um campo de valores, crenças, normas, hábitos e habilidades das classes dominantes, considerado como adequado à promoção do desenvolvimento psicológico sadio, desconsiderando outros critérios e parâmetros de avaliação. Em geral, as referidas pesquisas indicam que as crianças das camadas populares crescem numa família e numa cultura que impedem o desenvolvimento de suas potencialidades intelectuais e cognitivas. A diferença do modo de vida das crianças é percebida como desvio ou em defasagem que precisam ser corrigidos por meio da Educação Compensatória (Patto, 1983). Assim, a Psicologia colecionou afirmações, muitas vezes, preconceituosas sobre essas crianças e o que elas "não sabem" ou "não conhecem" ou que "deveriam conhecer", ignorando os seus saberes, suas capacidades e habilidades.

Dessa forma, tornaram-se relevantes estudos que buscam conhecer as crianças a partir da sua realidade social, da cultura da qual fazem parte e também são capazes de produzir. Como Castro (2001a) afirma, a Psicologia da Infância teria por tarefa produzir "narrativas do presente", ou seja, compreensões localizadas e parciais que dizem respeito a nossa época sem a pretensão de dar conta da totalidade ou de criar uma noção universalizante de infância, que seria comum a todas as culturas. Sarmento (2007) também chama a atenção para a necessidade de construir uma ciência que atenda às complexidades das condições de existência das crianças e que resgate a voz delas, desconstruindo imagens já estabelecidas e permanecendo alerta para impedir a cristalização de novas imagens redutoras da experiência de infância.

Segundo Castro (2001b), a criança participa do processo de produção e reprodução da cultura pelo seu agir, sua maneira de intervir no mundo, assim como os adultos. As ações são singulares e únicas, como formas de ser e de estar, e coletivas, na medida em que são contextualizadas e situadas histórica e socialmente. A ação põe em movimento outras ações, num processo de intervenção contínua e permanente nos acontecimentos do mundo. A subjetividade da criança vai sendo construída a partir de suas ações, que reelaboram e recriam o que está ao seu redor. A criança traz um conhecimento consigo, marcado pela sua história, por isso, "não pode ser vista apenas como um receptáculo que recebe imagens de maneira acrítica" (Pereira, Cerdeira, Andreiuolo, \& Souza, 2005, p. 115) e passiva.

O cotidiano das crianças na favela é perpassado pelas redes de relações construídas na vizinhança, na escola, na família, entre outros. As oficinas realizadas com as crianças da Babilônia, analisadas neste artigo, evidenciaram que nessa favela elas se sentem seguras para perambular, explorar e conviver, nos diferentes espaços. Enquanto a casa remete ao polo dos adultos, em que as crianças se encontram submetidas às normas e regras familiares, os becos, praças e vielas remetem ao polo de convivência com os pares, onde elas podem construir suas próprias regras, mediante os jogos e as brincadeiras. As crianças ocupam a favela, marcando o seu território de domínio e transformando-o em um lugar.

Compreendemos o lugar como um espaço vivido, apropriado pelo indivíduo através do processo de identificação e de sua ação sobre ele. Para Tuan (1983), espaço e lugar são conceitos distintos. Enquanto o primeiro é abstrato e indiferenciado, o segundo é dotado de valor. É nessa dimensão do lugar, fruto de lembranças, histórias e afetos que abordamos, no presente artigo, a relação das crianças com a favela. $\mathrm{Na}$ pesquisa de Lopes (2007) com crianças migrantes, o autor chama a atenção para os espaços de convivência coletiva que ganham relevância na experiência singular de ser criança, no encontro com as outras e com os adultos. Na presente investigação, discutiremos de que modo os espaços são transformados em lugares pelas crianças, uma vez que elas os conhecem e estabelecem vínculos com eles, revelando em tal relação uma forma singular de infância e de construção da cidadania.

A experiência cotidiana de crianças e adultos, permeada pela aprendizagem, amor e identificação com o lugar, possibilita a ambos vivenciar, individu- 
al e coletivamente, os caminhos trilhados e a se sentir implicados nos problemas e nas dificuldades que a vida coletiva lhes impõe. Tornar-se cidadão significa "poder descobrir, com os outros, que a cidade não está pronta, mas é 'obra' a ser construída" (Pérez, Póvoa, Monteiro, \& Castro, 2008, p. 33). Problematizamos, assim, a concepção clássica de cidadania definida como um estatuto político que se dá pelo usufruto de direitos cívicos, políticos, sociais conferidos pela lei aos jovens a partir dos 16 ou 18 anos e, ao mesmo tempo, pelas obrigações e deveres para com a comunidade. Nesta perspectiva moderna de cidadania, crianças foram excluídas dos espaços públicos de discussão e decisão, restringindo-se ao espaço da casa e da escola, instituição esta responsável pela preparação dos futuros cidadãos. Mais do que um conjunto de direitos e deveres, entendemos, neste artigo, a cidadania como um sentimento construído internamente pelo sujeito, por meio de sua ação no mundo. Promover a cidadania entre as crianças significa tirá-las de uma posição de invisibilidade e inserir a sua participação nos rumos da sociedade, de maneira que elas tenham o direito de querer uma sociedade diferente e o dever de construí-la.

Sendo assim, o presente artigo busca compreender como as crianças se apropriam da favela, identificandose e agindo sobre seus espaços. A partir de um estudo empírico com crianças moradoras da Babilônia, no Rio de Janeiro, investigamos suas ações, usos e brincadeiras nos lugares onde moram e frequentam. Além disso, buscamos identificar os problemas da favela que as afetam, suas opiniões sobre eles e suas possibilidades de participação nesse contexto.

\section{A oficina com crianças: abrindo espaço para a participação e discussão sobre a vida na favela Babilônia}

Com cerca de 2500 habitantes (IBGE, 2013), a Babilônia é considerada uma favela de pequeno porte no contexto da cidade. Ela e sua vizinha, Chapéu Mangueira, estão situadas na zona Sul do Rio de Janeiro, no bairro do Leme. Ultimamente, tais favelas têm atraído turistas e diversos empreendimentos públicos e privados, cujo objetivo é torná-las "comunidades modelo de sustentabilidade". Na época desta investigação, diferentes projetos de segurança e intervenção urbana estavam em curso na Babilônia: a Unidade Polícia Pacificadora - UPP, inaugurada em 2009, que visava promover uma atuação permanente da polícia em territórios que antes eram ocupados pelo tráfico de drogas; a UPP Social, com início em 2011, que tinha a intenção de melhorar a articulação entre as demandas locais e as ofertas de serviços públicos e privados; e o programa Morar Carioca, iniciado em 2011, com o objetivo de implantar obras de infraestrutura, acessibilidade, construção de habitações e remoção de famílias em áreas de risco.

Diante dessas intervenções em curso na favela, foram realizadas oficinas com crianças ${ }^{1}$, abrindo espaço para a discussão e a ação frente às transformações vivenciadas por elas no lugar onde moram. Meninas e meninos puderam dar suas opiniões e iniciar um processo de diálogo aberto às imprevisibilidades do encontro com o outro (Oliveira $\&$ Castro, 2009). Fizeram parte 35 crianças, de ambos os sexos, com idades entre 5 e 10 anos, moradoras da Babilônia, reunidas em três grupos, de acordo com a faixa etária. Duas psicólogas e uma pedagoga fizeram a coordenação das oficinas. Buscando fugir do "artificialismo da pesquisa" (Castro, 2008) e promover a convivência com as crianças em seus contextos, as atividades foram feitas, em parceria com uma instituição comunitária local, que oferecia aulas de reforço escolar, lazer e alimentação, nos horários de contraturno escolar. Também foram feitas reuniões com as educadoras dessa instituição em que pudemos conhecer suas perspectivas sobre as crianças e as mudanças que estavam acontecendo na favela.

As oficinas ocorreram durante os meses de maio e junho de 2012. Dentre as atividades (CECIP, 2013), propusemos um jogo sobre os caminhos que as crianças percorrem de casa até o projeto de contraturno escolar ou até a escola municipal onde estudam, para conhecer os percursos que elas faziam no seu dia a dia e como percebiam estes lugares. Realizamos uma discussão a respeito do universo de brincadeiras infantis e da forma como as crianças se apropriam dos espaços para seus encontros lúdicos e sociais. Produzimos um vídeo com as crianças acerca dos problemas que afetam as suas vidas. Durante a sua construção, elas puderam propor perguntas que lhes instigavam e escolher crianças e adultos para entrevistar, interagindo com seus colegas, operários da obra do Morar Carioca, segurança e pacientes do posto de saúde. Também foi criado um mapa afetivo, a partir das histórias vividas e das lembranças narradas sobre os espaços onde estudam, brincam, frequentam, aqueles considerados atraentes e/ou perigosos, situados na Babilônia, Chapéu Mangueira e Leme.

Outra atividade realizada foi o passeio fotográfico com crianças e educadoras para a Pedra do Telégrafo, parte mais alta da Babilônia. Nesse passeio, elas caminharam por uma trilha ecológica e entraram em contato com a história de ocupação do morro. Usando máquinas fotográficas, as crianças puderam registrar o que encontraram no caminho: as casas onde mora- 
vam, as moradias antigas que seriam demolidas pela obra, o prédio em construção, a paisagem vista do alto, os animais, as pessoas, entre outros. Ao final, foi realizada uma devolutiva, na qual as crianças puderam relembrar as diferentes atividades e compartilhar suas impressões sobre o projeto.

Todos os encontros foram registrados pelas coordenadoras em cadernos de campo e em fotografias. Alguns foram também registrados em vídeo. Após as oficinas, foram feitos relatórios que reuniam informações contidas nesses diversos registros e consideravam as impressões, os afetos e os sentimentos emergentes durante o processo de intervenção, que serviram como base para a discussão apresentada neste artigo. Desse modo, buscamos, na riqueza potencial da pesquisa de campo, reconhecer o lugar da subjetividade e dos laços intersubjetivos entre os participantes das oficinas. Entendemos que o uso dessa metodologia com crianças implica repensar o lugar que elas ocupam na sociedade em que vivemos e as repercussões que a pesquisa pode trazer para as suas vidas.

Os resultados obtidos nas oficinas foram analisados no presente artigo a partir de três eixos temáticos: "As apropriações do espaço da favela pelas crianças através do uso e das brincadeiras", "Problemas da Babilônia: propostas de encaminhamentos individuais e soluções criativas", "A obra do Morar Carioca: o impacto na vida das crianças e a expectativa de melhorias na favela".

\section{As apropriações do espaço da favela pelas crianças através do uso e das brincadeiras}

Hoje em dia, o modo de vida das crianças moradoras de cidades grandes, como o Rio de Janeiro, sofre uma crescente institucionalização e privatização dos espaços frequentados. No caso das crianças de classe média e alta, tal processo se dá de forma mais intensa, uma vez que elas passam várias horas do dia em casa, jogando videogames, navegando na internet e em sites de redes sociais. Além da escola, passaram a ter um cotidiano preenchido por inúmeras atividades complementares a sua formação, como línguas estrangeiras, esportes, dança, permanecendo, a maior parte do tempo, vigiadas, sob o controle e a tutela dos adultos (Sarmento, Fernandes, \& Tomás, 2007). Os seus momentos de lazer se dão nos shoppings, em áreas de recreação dentro de prédios ou condomínios. Assim, "tem-se acirrado o isolamento das crianças que estão cada vez mais sozinhas, institucionalizadas em tempos e espaços específicos, experimentando relações restritas a seus próprios pares" (Martins, Debortoli, Teixeira, \& Arruda, 2009, p. 7).
Percebemos que as crianças moradoras da Babilônia, ainda que permaneçam grande parte do seu dia em espaços institucionalizados, como na escola e no projeto de contraturno escolar, vivenciam o tempo livre fora de suas casas, brincando com outras crianças, ocupando os becos e os espaços comuns da favela. Elas possuíam uma rede de amizades, conheciam seus vizinhos e muitos deles faziam parte da sua família. Segundo um menino, "na vila, as crianças é tudo meu primo", mostrando que havia uma rede afetiva e familiar da qual ele fazia parte na favela. Assim como Coelho (2007), observamos que a relação da criança moradora de favela com o espaço onde sua vida cotidiana se dá lhe assegura os sentimentos de segurança, liberdade e aventura, contribuindo para seu processo de enraizamento. A criança "busca experimentar todo o espaço que está ao seu alcance e se identifica nele mediante suas conquistas, descobertas e diferentes ações" (Coelho, 2007, p. 178).

Durante as oficinas, os grupos contaram muitas histórias de atividades que desenvolviam ao ar livre e em contato com a natureza. Fazia parte da realidade dessas crianças subir em árvores para pegar frutas, pescar, encontrar bichos na mata, como cobras, gambás, micos, além de brincar com os seus gatos e cachorros. Durante uma atividade em que as crianças falaram sobre as brincadeiras que elas mais gostavam, um menino desenhou duas árvores e disse: "Eu subo na árvore pra pegar fruta, a gente aqui é nascido no mato". As crianças também contaram histórias de cobras que foram encontradas na escola e usadas na brincadeira para assustar os colegas. Os meninos disseram gostar de soltar pipas em diferentes lugares: nas lajes, na Caixa d'água, na Pedra do Urubu, no Campinho e no Chapéu Mangueira. Apesar de algumas meninas também soltarem pipas, essa brincadeira é vista pelas crianças como predominantemente masculina. Um menino aprendeu com o seu avô, que vendia pipas e promovia campeonatos na favela, a fazê-las. Nesse caso, a pipa possibilitou uma troca geracional entre o menino e o seu avô.

As crianças relataram, dentre as brincadeiras preferidas, dois jogos que foram criados pelas crianças daquele local: o pique-abobrinha e o piquelateiro. Segundo um morador da Babilônia, o piquelateiro existe ali desde que ele era criança, há mais de vinte anos. Essas brincadeiras foram passadas entre gerações e permaneciam entre as favoritas das crianças. Acontecendo sem a mediação de adultos, elas próprias inventavam os roteiros e negociavam as regras. As crianças também gostavam de brincar de pique-esconde porque podiam se esconder na mata. Em geral, as crianças pequenas escolhiam brincar na 
própria rua ou em lugares próximos, pois tinham medo de se perder.

Os espaços da favela se diferenciavam pela possibilidade de reunir mais crianças, por serem planos, terem vento, entre outros aspectos, fazendo com que variassem os tipos de brincadeira desenvolvidos ali. O pátio em frente à instituição de contraturno escolar era muito usado pelas meninas para brincar de boneca, pular-corda e rodar bambolê. A Caixa d'água, por sua vez, era um local muito frequentado para brincar de pique-esconde, pique-pega e, conforme uma criança, "dá até pra brincar de tudo". De acordo com uma educadora, naquele espaço funcionava uma caixa d'água que fornecia água quando havia cerca de 300 famílias morando na Babilônia. Hoje em dia, ela já foi desativada, sobrando um local plano, cimentado, como uma grande laje.

O Campinho era outro lugar frequentado pelas crianças para jogar bola, realizar campeonatos de futebol e pipa, e para diferentes eventos, como a festa junina em que dançavam quadrilha. Já a quadra da FAETEC era um espaço utilizado pelas crianças para desenvolver atividades mediadas por um adulto, como cursos de música, informática, prática e campeonato de esportes, entre outros. Dificilmente elas frequentavam a quadra da FAETEC para brincar, no dia a dia, de forma livre e espontânea. As crianças também contaram muitas histórias sobre a "Pedra do Urubu", um local mais afastado das casas e, perto do mar, usado para pescar e soltar pipa. Uma menina nos relatou os passeios em família para a Pedra do Urubu:

Um dia subiu eu, meus irmãos, e meu pai para pescar. Minha irmã, que nunca pescou, ela pegou 12 peixes. Eu peguei 4 e meu irmão, que pescava todo dia com o meu pai, pescou 3. Um dia a gente foi lá pra pegar jaca e só estava eu, meu irmão, minha irmã mais velha e outro irmão. A gente ouviu o passo de gente e a gente rolou. Depois a gente subiu com o meu pai e a gente pegou jaca, jaca-esmalte, jaca-pau, jaca de muitas coisas.

No passeio que realizamos para a Pedra do Telégrafo, as crianças exploraram bastante o local: entraram no mato, atentas aos bichos e ao que estava no chão; soltaram pipas no alto da pedra; brincaram em volta de uma poça com uma água esverdeada, que deram o nome de "água do urubu, porque é onde o urubu bebe água”; brincaram que havia jacarés nadando ali, por causa dos formatos das pedras que se assemelhavam a esse bicho. Percebemos que as crianças ficavam à vontade na interação com a natureza. Algumas conheciam bem a Pedra do Telégrafo, já outras, as mais novas, brincavam como se fosse a primeira vez. Em geral, as crianças pequenas visitavam pouco aquele local, pois dependiam da companhia dos adultos ou de outras crianças mais velhas para chegarem até lá, uma vez que o percurso era um "caminho de mato", uma trilha saindo da favela.

Outros lugares que apareceram no mapa afetivo das crianças foram: a praia do Leme e o Calçadão, passeio público que beira a orla. Quando estávamos fazendo a trilha do passeio, avistamos a praia do Leme do alto. Um menino apontou e disse: "É a praia do morro!", mostrando, assim, que esta praia fazia parte do espaço afetivo entendido como o morro da Babilônia. As crianças iam à praia com suas famílias, principalmente nos finais de semana, para jogar bola e nadar. Elas nos relataram diversas "aventuras" e situações perigosas que viveram na praia. Mergulhar no mar era visto como arriscado, onde podiam se machucar, se afogar e até morrer.

As crianças costumavam ir ao Calçadão, tanto nos finais de semana, quanto no horário antes ou depois da escola, geralmente, acompanhadas por adultos. Como elas moravam no morro cheio de ladeiras e escadas, algumas brincadeiras só eram possíveis de acontecer ali, em um espaço plano e amplo. Por ser fora da comunidade, o Calçadão se apresentava como um lugar menos familiar, onde se encontravam com pessoas desconhecidas. Uma menina disse: "Lá no calçadão é muito bom porque dá pra andar de patins, de patinete, dá pra andar de tudo. Mas também é muito chato porque as pessoas só sabem ficar esbarrando quando a gente está passando". Nessa fala, percebemos uma queixa sobre a indiferença, que marca as relações entre estranhos nas grandes cidades. Outra menina relatou uma história de um grupo de mendigos que "mexeram" com ela enquanto passeava com sua mãe, à noite no Calçadão. $\mathrm{O}$ mendigo gerou medo $\mathrm{e}$ apreensão. A menina precisou da intervenção da mãe para sair daquela situação constrangedora. Nesse caso, a relação com o desconhecido não se deu pela indiferença, mas pelo incômodo e mal-estar.

Podemos aproximar tal sentimento relatado pelas crianças com a perspectiva de Simmel (2005) sobre o comportamento blasé. Já no início do século XX, o autor considerava esse comportamento como sendo necessário para que os habitantes dos centros urbanos pudessem manter a sua integridade psicológica, já que eram incapazes de responder a tantos estímulos e contatos com pessoas ao longo do dia. A postura blasé, ao mesmo tempo que protegia o indivíduo dos choques cotidianos a que está submetido, também impossibilitava o seu afetamento pelo mundo que o cerca. A experiência de viver na multidão produziu, assim, indivíduos solitários, indiferentes. Nesse caso, as crianças, acostumadas a viver em um local onde 
os moradores são conhecidos e estão protegidas pela relação de vizinhança e parentesco, estranhavam esse contato com pessoas que não se cumprimentavam, que "esbarravam" umas nas outras, não se importando com a presença delas.

Segundo Castro (2001a), "a cidade grande demanda desenraizamento e distância dos laços originais de família" (p. 126), pois ela é um espaço no qual as relações sociais se diferem daquelas estabelecidas no ambiente protetor e acolhedor das comunidades pequenas, onde o indivíduo possui um sentimento de pertencimento ao lugar de origem e encontra-se localizado como um elemento na cadeia de gerações. As falas das crianças da Babilônia evidenciam que, no Rio de Janeiro, coexistem diferentes experiências subjetivas que os habitantes estabelecem entre si e com o espaço. Dentro de um mesmo bairro, no caso o Leme, a desigualdade social também se traduz nas formas distintas das pessoas se relacionarem com os outros. Para as crianças, a favela da Babilônia é um lugar seguro, em que todos são conhecidos e onde as crianças são olhadas pelos adultos, aproximando-se da experiência da comunidade pequena, tal como afirma Castro (2001a). Já no Calçadão, elas vivenciam o desenraizamento, tornando-se invisíveis diante dos desconhecidos. As crianças da Babilônia transitavam, portanto, por esses diferentes universos simbólicos, aprendendo a viver e a conviver na cidade grande.

Outro aspecto que notamos ao longo das oficinas diz respeito às tensões que existiam entre as crianças moradoras das favelas Chapéu Mangueira e Babilônia. Apesar de só existir uma rua que separa uma favela da outra, as crianças da Babilônia não costumavam frequentar o Chapéu Mangueira para brincar. Essa demarcação do território pôde ser percebida em diferentes momentos das oficinas, como, por exemplo, na ocasião em que um menino comentou que havia se mudado para o Chapéu Mangueira, pois a sua casa ficava em área de risco. As crianças implicaram com ele, dizendo: "Ele não é mais daqui!". Em outro grupo, um menino disse de forma agressiva que não gostava de quem morava no Chapéu Mangueira porque "lá tem muito cocô", referindo-se às pessoas. Outro garoto complementou: "Os meninos do Chapéu não é do nosso bonde, nem da nossa raça". Ser do mesmo "bonde" pode significar o pertencimento a um mesmo grupo, que possui gostos comuns, que brinca das mesmas coisas, cujos integrantes moram próximos uns aos outros, e assim por diante. Existiam, nesse caso, alguns limites e fronteiras simbólicas no território que diferenciavam aqueles que pertenciam à Babilônia e ao Chapéu Mangueira.
Entretanto, outras crianças ponderaram sobre essa separação: "Lá no Chapéu é muito feio, mas a gente brinca na quadra da FAETEC". A quadra, por ficar na ladeira Ary Barroso, era considerada um território comum, frequentado pelas crianças das duas favelas, assim como a escola. Diferentemente dos meninos que não se aproximavam das crianças da outra favela, meninas citaram nomes de amigas da escola que moravam no Chapéu Mangueira, evidenciando uma diferença de gênero, no que se refere a essa rivalidade. Para uma educadora, as crianças repetem o discurso dos pais sobre a divisão do morro, "isso acontecia no passado. Hoje em dia o morro é unido".

Em diversos momentos, quando perguntadas sobre a Babilônia, as crianças contavam histórias acerca de suas escolas, expressando opiniões e críticas a respeito da instituição onde estudavam. Elas frequentavam duas escolas municipais, uma delas localizada no bairro do Leme e, outra, em Copacabana. A vida na escola parecia se confundir com a vida na favela, visto que muitos colegas de turma eram também vizinhos e familiares, com os quais compartilhavam histórias e situações diariamente. Para um menino: "Lá é muito bom, é muito legal. A professora deixa a gente ficar brincando. E lá tem um campo, dá para jogar futebol". Do ponto de vista do grupo que participou da oficina, uma boa escola é aquela que passa deveres de casa, oferece aulas interessantes e permite às crianças brincarem. A brincadeira surgiu como uma maneira de a criança interagir com a escola, qualificando-a positivamente.

Ao longo da investigação, notamos que essa experiência de infância se distancia da infância urbana correntemente retratada, na qual há um "esvaziamento das práticas espontâneas, do encontro, do ócio, do convívio social e cívico, do tempo da brincadeira, do riso" (Martins et al. 2009, p. 8). As crianças se reuniam para brincar e interagiam em diversos espaços da favela. Conforme Coelho (2007), "a brincadeira é uma das interações habituais da infância que transformam, por meio da imaginação, o espaço vivido em espaço afetivo" (p. 177). Já para Winnicott (1975), é no brincar que a criança frui sua liberdade de criação, processo saudável no qual o indivíduo se relaciona com seu contexto num "viver criativo". As crianças pareciam exercer esse "viver criativo" na medida em que transformavam um espaço qualquer, em um lugar de afeto, seu e do seu grupo. Pelas brincadeiras, as crianças ressignificavam o seu entorno, estabeleciam relações, construíam suas opiniões. Em sua dimensão coletiva e relacional, a ação faz com que a própria criança se modifique, possibilitando a construção do sentimento de fazer parte daquele lugar. 


\section{Problemas da Babilônia: propostas de encaminhamentos individuais e soluções criativas}

Nesta seção, discutimos os principais problemas que afetam a vida na Babilônia e os possíveis encaminhamentos para resolvê-los, na perspectiva das crianças. Ao longo das oficinas, elas falaram o quanto o lixo, as valas e os ratos afetavam suas vidas e contaram como lidavam com essas dificuldades. Meninos e meninas caracterizaram as valas como "cheias de mosca", com "abelhas que picam as crianças", "fedidíssimas", que "tem lixo e rato" e "junta sujeira e bicho". Para solucionar o problema do lixo, disseram que "tem que juntar e botar no cantinho" e "jogar o lixo no lixo". Para a manutenção da limpeza local, deviam "botar o lixo dentro do bolso e, quando chegar em casa, jogar fora". Esse tipo de resposta ao problema nos pareceu um "discurso pronto", ensinado na escola e pelos meios de comunicação, reproduzido como a maneira correta de agir, sem levar em consideração o papel do poder público e a deficiência dos serviços de limpeza urbana.

A solução dada pelas crianças para matar os ratos parecia se basear numa experiência prática que aprenderam com seus familiares. Segundo um menino, "o rato entra pelo buraquinho e tem que matar com veneno ou cerveja". É curioso notar que, para acabar com os ratos e o lixo, as crianças sugeriram ações que poderiam ser engendradas por elas mesmas, a partir da ideia de que seria preciso "cada um fazer a sua parte". Para elas, esses problemas que afetavam a vida de todos poderiam ser amenizados a partir de ações individuais e imediatas, as quais, muitas vezes, estavam ao seu alcance.

As crianças sinalizaram também como um problema da favela as dificuldades de deslocamento. Queixavam-se da quantidade de escadas e ladeiras que precisavam subir para acessar suas casas e diferentes lugares no morro. Na opinião desses meninos e meninas, as crianças eram as pessoas que mais sofriam com as escadarias. Eles disseram que "se cansar, é pra parar, respirar, descansar e depois continuar". Quando perguntamos se não haveria outras possibilidades para melhorar o deslocamento, alguns sugeriram a construção de rampas, pois, "se tivesse rampa, seria legal para descer de skate". Com isso, as crianças buscaram transformar uma dificuldade em algo que pudesse ser prazeroso e divertido.

Outro problema apontado foi a falta de manutenção dos equipamentos públicos e a falta de cuidado, por parte dos moradores, com a pracinha usada pelas crianças para brincar. Uma menina contou sobre uma praça que existia na favela: "Fizeram uma pracinha linda aqui, de tanto todo mundo quebrar, agora não tem nada". Outra disse, referindo-se à praça do Leme: "Tem muita sujeira e muito cocô de cachorro que os pessoal não limpa. E tem mendigo que dorme. Tem balanço quebrado, que estão quebrando, tá tudo quebrando. As casinhas que eles montaram tá tudo quebrando. Eles colocaram um escorrega novo, agora, já tá todo velho".

Uma solução dada para tal problema foi a cobrança de ingresso para usar a pracinha, afirmando que só assim as pessoas deixariam de quebrar os brinquedos. De acordo com essa perspectiva, o espaço que pertencia a todos não era valorizado pelos moradores, então, ao cobrar uma entrada, estes passariam a tomar mais cuidado com o local. A saída dada para o problema seria, portanto, a privatização do espaço, uma vez que o poder público e os moradores não preservavam e cuidavam da praça. Entendemos que essa solução evitaria o conflito entre os vizinhos, pois eles estariam recorrendo a alguém externo, capaz de instaurar a autoridade e a vigilância. Desse modo, não seria preciso negociar e tentar entrar em acordo com os outros moradores para criar as regras conjuntamente ou, então, criar uma mobilização para pressionar o poder público. A perspectiva de privatizar a praça, presente na fala das crianças e amplamente efetuada atualmente, acaba por não valorizar a participação e a discussão sobre os usos e os destinos dos bens comuns.

Ficou claro para nós que meninos e meninas entendiam a praça como um lugar importante para as suas brincadeiras e encontros sociais. Eles fantasiavam sobre as atrações que poderiam ter na praça: "Um tobogã de água", "um parque de diversões" e "uma fazenda para tirar leite da vaca e andar de cavalo". Assim, as crianças usavam a imaginação para projetar no espaço da favela ideias criativas, que poderiam torná-lo mais agradável e acolhedor para elas.

As oficinas mostraram, portanto, que as crianças se preocupavam com problemas de conservação e limpeza da Babilônia. Entendemos que a vivência das crianças nos espaços comuns da favela, a partir das brincadeiras realizadas fora de casa e pelo deslocamento a pé, permitiu que elas tivessem esse olhar atento aos problemas coletivos. Situação esta diferente, por exemplo, de crianças de classes mais abastadas, que utilizam o transporte individual, frequentam escolas particulares, e até mesmo áreas de lazer privadas, ficando, por conseguinte, mais protegidas das questões que afetam a todos. Apesar de as crianças da Babilônia vivenciarem problemas comuns, as 
soluções vislumbradas não se direcionavam para uma ação mais coletiva, que seria o resultado de discussões e do compartilhamento de projetos comuns ou que poderiam levar à responsabilização do poder público $\mathrm{e}$ à cobrança por melhorias. Ao invés disso, as crianças imaginaram soluções pontuais e ações que podiam ser realizadas por elas mesmas para transformar, de maneira lúdica e prazerosa, as situações desagradáveis com as quais conviviam.

\section{A obra do Morar Carioca: o impacto na vida das crianças e a expectativa de melhorias na favela}

As obras do programa de urbanização da prefeitura Morar Carioca foram tema de discussão em diversos momentos das oficinas. Essa intervenção na Babilônia teve início em 2011 e causou um grande impacto no cotidiano dos moradores, despertando o interesse e a curiosidade nas crianças. Elas ponderavam tanto sobre os aspectos ruins e os transtornos causados, quanto sobre as melhorias e os benefícios que a obra poderia trazer para a favela. Nesta seção, apresentamos os argumentos e as discussões que as crianças travaram sobre os problemas de moradia, saneamento e o programa de urbanização.

Em muitas ocasiões, as crianças fizeram reclamações sobre a maneira como a obra estava sendo conduzida, denunciando os seus transtornos, isto é, barulho, poeira, lama, sujeira que se espalharam por todo lado. Elas também falaram sobre a desordem nas vias de acesso à Babilônia e as dificuldades de locomoção, que resultavam em quedas e acidentes. $\mathrm{Na}$ opinião delas, a intervenção na ladeira Ary Barroso provocou um dos maiores problemas, pois proibiram o acesso de veículos. "Não dá mais para subir de kombi, tem que subir com as sacolas a pé", segundo uma criança. Durante uma das atividades, um menino disse que gostaria de falar para os engenheiros "sobre esse estrago que eles estão causando, sobre a lama na ladeira, porque quase que eu escorrego". Percebemos pelas falas das crianças e pela nossa experiência ao caminhar na favela que não foram criadas iniciativas consistentes para facilitar o deslocamento pelo morro, como a criação de escadas provisórias seguras ou de passagens de madeira elevada em número suficiente. Entendemos que toda obra gera transtornos, no entanto, poderiam ter sido pensadas, com a participação das crianças e dos demais moradores, formas de reduzi-los.

Outro aspecto abordado pelas crianças foi o assédio dos homens contratados para trabalhar na obra às meninas e mulheres que circulavam pela favela. As meninas contaram histórias em que homens adultos falaram "gracinhas" para elas, ficaram "olhando de cima para baixo", despertando a raiva e a vontade de xingá-los. Esse assunto mobilizou um dos grupos que comentou, em diferentes encontros, sobre tal mal-estar. Podemos afirmar que a chegada de homens de fora da comunidade para trabalhar na obra provocou diversas mobilizações afetivas, desconfortos e inseguranças entre as crianças.

A obra também modificou espaços que as crianças usavam para brincar, como a antiga pracinha e o Campinho de terra. Uma menina comentou chateada: "Tiraram a pracinha da gente para construir um prédio", e outra disse: "A gente ia de noite na pracinha, lá tinha brinquedo, balanço, escorrega, gangorra, roda. Agora a gente tem que ir na pracinha do Calçadão". Conforme uma educadora, durante muito tempo a praça citada pelas crianças estava em péssimas condições, mas uma obra promovida por uma empresa particular fez reparos nos brinquedos. Durante cerca de seis meses, as crianças puderam desfrutar da praça dentro da favela para brincar e encontrar os amigos. Todavia, com o início do programa Morar Carioca, a praça recémreformada foi destruída para ter o seu espaço ocupado pelo canteiro de obras. As crianças sentiram muito a sua perda e aguardavam ansiosamente o momento em que a praça seria reconstruída.

Em relação ao Campinho, as crianças disseram em tom fatalista: "Agora vai cimentar, aí não vai dar mais pra jogar futebol", uma vez que "antes tinha muita terra, era bom para jogar". Um menino disse: "A Dilma vai vir aqui cimentar isso tudo!", e outro complementou: "A gente prefere (o Campinho) com grama!". O ato de cimentar, lembrado pelo menino, é uma boa metáfora para o projeto de progresso e desenvolvimento empenhado pelos governos federal e municipal que, muitas vezes, desconsideram o modo de vida local. A partir do momento em que o cimento passa a ser o solo do morro, as brincadeiras e os hábitos das crianças também se modificam. Um exemplo que nos relataram foi que jogar bolinha de gude fora de casa, no chão de terra, porque assim se faz os buracos e obstáculos da brincadeira no chão, não seria mais possível.

Nesse caso, fica evidente como o poder público age de maneira impositiva nos espaços da favela, sem promover qualquer discussão com as crianças a respeito dessas intervenções e sem fazer um levantamento prévio das suas opiniões sobre as mudanças que gostariam que acontecessem ali. Na nossa sociedade, há uma invisibilidade cívica em relação às crianças (Sarmento, 2007; Sarmento, Fernandes, \& Tomás, 2007), já que estão "naturalmente" privadas do exercício de direitos políticos, ficando excluídas das esferas de 
decisão coletiva e de participação. Crianças e jovens constituem a geração mais distante dos políticos, porém são os que sofrerão por mais tempo as consequências das escolhas políticas de agora. De acordo com Sarmento (2007), "não votando e nem sendo eleitas, as crianças são tematizadas fora do quadro do referencial de destinatários políticos, designem-se eles como 'cidadãos', 'contribuintes', ou mesmo 'povo'. E, no entanto, qualquer medida de política afecta diferenciadamente as várias gerações.” (p. 38). Dessa forma, apesar de as crianças terem interesses específicos, não possuem espaços para participarem, o que leva os políticos a prestarem menos atenção às suas opiniões $\mathrm{e}$ necessidades. Possivelmente, elas serão as pessoas que viverão a maior parte do tempo na favela, por isso, entendemos que seria justo que pudessem participar das mudanças que estão acontecendo ali.

Apesar da falta de participação das crianças nas intervenções urbanas na Babilônia, algumas estavam esperançosas com melhorias que o programa Morar Carioca poderia trazer para as suas vidas. Um menino, refletindo sobre as condições de vida na favela, disse: "Na ladeira sempre acontecia coisas ruins. Nada de bom acontecia. Antigamente estourava o bueiro e ficava vazando meses, meses, na ladeira Ary Barroso. E também, às vezes, quando não era esgoto, era luz, poste pegando fogo". Nesse caso, as intervenções deram visibilidade aos problemas enfrentados pelos moradores, que passaram a contar com uma atenção maior dos prestadores de serviços públicos. As crianças esperavam que a obra as afetasse positivamente, trazendo melhorias na manutenção e preservação dos equipamentos e serviços. Outra criança, durante a oficina, narrou a situação da Babilônia antes da obra e avaliou positivamente as mudanças:

Era tudo sem saneamento, escorria esgoto. Era qualquer chuva que caia, transbordava, caia bastante água de esgoto para cá pra baixo, na ladeira. E as casas também eram tudo irregular, não era casa segura para ficar ... Então eles quebraram tudo e estão construindo um (prédio) novo para melhorar. Eles vão melhorar bastante e vão botar as pessoas que eles pediram para ir embora.

A situação das casas em áreas de risco surgiu em diversos momentos do trabalho como uma das "coisas ruins" com as quais as crianças conviviam. Algumas falaram das casas de madeira e barro que ficavam na área do morro chamada de Vila. Um garoto contou: "Quando eu morei lá, minha casa caiu por causa da chuva". Meninos e meninas nos contaram histórias de acidentes decorrentes de chuvas, remoções e mudanças de endereço dentro da própria favela. Durante uma atividade, uma menina questionou: "É justo ficar com essas casas toda quebrada? Tem que consertar, não dá para ficar com essa casa toda bagunçada", e concluiu: "Eu não quero ficar aqui não". Esta fala, em tom de revolta, pode ser compreendida como um apelo para que o poder público faça alguma coisa para resolver a precariedade da moradia. Mais do que uma afirmação sobre um problema que a afeta particularmente, a menina fez uma reflexão acerca de uma situação de injustiça social, que afeta todos que vivem ali. O "prédio novo", construído pela prefeitura para abrigar os moradores dessas áreas, foi visto como uma alternativa positiva e considerado como uma das "coisas boas", dentre as mudanças que estavam ocorrendo.

Como vimos, as crianças apresentam uma perspectiva complexa em relação às intervenções. Se, por um lado, contaram ressentidas que a obra ocupou áreas onde antes costumavam brincar, gerou transtornos, dificultou a locomoção e trouxe para o convívio diário pessoas estranhas que causam desconfiança e, até mesmo, raiva; por outro lado, há uma expectativa de que a obra represente uma maior atenção do poder público e traga melhorias como o saneamento básico e a construção de moradias mais seguras para suas famílias.

\section{Considerações finais}

A experiência de infância na favela da Babilônia é marcada pela brincadeira fora de casa realizada coletivamente com os pares e pelo contato com a natureza. As crianças ocupam espaços destinados à infância, como a pracinha, a escola e os projetos de contraturno escolar, mas também fazem uso da mata, dos becos, da praia, do Campinho, da Caixa d'água, entre outros lugares da favela. A circulação das crianças se dá, predominantemente, na Babilônia e no bairro do Leme.

Quando elas saem da favela para brincar no Calçadão, entram em contato com estranhos, vivenciando a experiência urbana, tal como aponta Simmel (2005). Lá elas podem encontrar pessoas desconhecidas que "esbarram", demonstrando sua indiferença, e os mendigos, que as perturbam e incomodam. Embora as crianças frequentem uma escola no Leme, isso não garante o contato e o convívio com crianças de diferentes classes e contextos sociais, pois na escola encontram-se principalmente crianças da Babilônia e do Chapéu Mangueira. Rua (2007), em seu estudo com crianças moradoras de bairros populares em Portugal, chegou à conclusão semelhante: "A sua casa é no bairro, o jardim de infância é no bairro, a sua escola é no bairro, e frequentada, quase exclusivamente, por crianças do bairro" (Rua, 2007, p. 221). 
Com a circulação pelas áreas comuns da favela e do bairro, as crianças ficam também expostas ao que acontece nesses espaços, potencializando o seu olhar para aquilo que é público. $\mathrm{O}$ fato de elas não estarem tão protegidas na esfera privada faz com que construam um conhecimento do lugar onde moram e sejam mais afetadas pelo que acontece no seu entorno. Pelas brincadeiras, as crianças se apropriam do espaço da favela e a transformam num lugar "seu", permeado de afetos e histórias. Por outro lado, elas também entram em contato com os seus diferentes problemas.

As crianças compreendem que as soluções para alguns dos problemas, como o lixo e o rato, podem ser realizadas também por elas, uma vez que os tomam como o resultado da falta de respeito e de responsabilidade dos moradores com o espaço comum. No entanto, apontam que outros problemas precisam da intervenção pública e, por isso, veem as obras de urbanização como sendo necessárias. Há a expectativa de que o programa Morar Carioca possa proporcionar melhorias, como o saneamento básico e a construção de moradias mais seguras para suas famílias.

Durante as atividades, notamos que as obras geraram transtornos e impactos no dia a dia das crianças, interferindo nos espaços da favela e, consequentemente, nas suas brincadeiras. Os resultados desta investigação mostram que as crianças pensam de maneira complexa o lugar onde moram, desejam melhorias e criticam aquilo que não vai bem. A criação de um espaço de fala e reflexão durante as oficinas e a maneira ativa como elas interagiam com os espaços comuns permitiram a "expansão do olhar" para o lugar onde vivem, favorecendo a construção do sentimento de cidadania. Ao interagirem com os espaços da favela, as crianças também interagem com a história coletiva, com a ideologia, e constroem um conhecimento marcadamente cultural. Concordamos que, "se for dada a possibilidade de fala e de representação (para as crianças), certamente a experiência do homem contemporâneo tão marcada pelo empobrecimento de relações verdadeiramente significativas irá enriquecer" (Pereira et al. 2005, p. 115). A abertura para a participação infantil possibilitaria aos adultos envolvidos nas obras do Morar Carioca novos olhares para o local, visto que a sua perspectiva técnica, enrijecida e racionalizada seria interpelada pelas relações afetivas e criativas das crianças com o lugar. $\mathrm{O}$ encontro com a infância, como uma alteridade, pode possibilitar ao adulto reconhecer os seus limites, faltas e incompletude, assim como descobrir novas formas de criação de si mesmo e do mundo.

No entanto, as opiniões das crianças não são consideradas nos espaços públicos de discussão e decisão, e tampouco na construção dos projetos de intervenção do lugar onde vivem e frequentam. Os sentidos construídos por elas e suas maneiras próprias de lidar com o espaço não são levados em conta pelo poder público nas obras de infraestrutura e urbanização. Engenheiros e arquitetos dificilmente observam as crianças ou se aproximam delas para conhecer suas perspectivas. Dessa maneira, elas ficam alijadas das formas de participação e da discussão sobre os rumos da favela e, de forma mais ampla, da cidade. Existe ainda um longo caminho a percorrer para que as crianças saiam da "invisibilidade cívica" e sejam consideradas aptas a participar das mudanças sociais no momento presente de suas vidas.

\section{Nota}

Essas oficinas foram realizadas pelo Projeto Criança Pequena em Foco, desenvolvido pelo CECIP - Centro de Criação de Imagem Popular, com apoio da Fundação Bernard van Leer e em parceria com o Instituto Pereira Passos. O projeto buscava criar estratégias para incluir a participação das crianças na orientação das políticas públicas, nas intervenções de infraestrutura do espaço e dos equipamentos urbanos a elas direcionados.

\section{Referências}

Castro, L. R. (2001a). Crianças, jovens e cidades: vicissitudes da convivência, destinos da cidadania. In L. R. Castro (Org.), Subjetividade e cidadania: um estudo com crianças e jovens em três cidades brasileira (pp. 113-156). Rio de Janeiro: 7 Letras.

Castro, L. R. (2001b). Da invisibilidade à ação: crianças e jovens na construção da cultura. In L. R Castro (Org.), Crianças e jovens na construção da cultura (pp. 19-46). Rio de Janeiro: Nau.

Castro, L. R. (2008). A pesquisa intervenção e o diálogo com os agentes sociais. In L. R. Castro \& V. L. Besset (Orgs.), Pesquisa-intervenção na infância e juventude (pp. 21-42). Rio de Janeiro: Trarepa/Faperj.

Centro de Criação de Imagem Popular - CECIP. (2013). Vamos ouvir as crianças? Caderno de metodologias participativas do Projeto Criança Pequena em Foco. Rio de Janeiro: Autor.

Coelho, G. N. (2007). Brincadeiras na favela: a constituição da infância nas interações com o ambiente. In V. M. R Vasconcellos \& M. J. Sarmento (Orgs.), Infância (in)visível (pp. 173-203), Araraquara, SP: Junqueira \& Marin.

Gouvea, M. C. S. (1993). A criança de favela em seu mundo de cultura. Caderno de Pesquisa, 86, 48-54.

Instituto Brasileiro de Geografia e Estatística - IBGE. (2013). Censo 2010. Brasília, DF: Autor. Acesso em 25 de abril, 2013, em http://www.censo2010.ibge.gov.br/

Lopes, J. J. M. (2007). Espaço, lugar e territórios de identidade: a invisibilidade das crianças migrantes. In V. M. R Vasconcellos \& M. J. Sarmento (Orgs.), Infância (in)visivel (pp. 151-172), Araraquara, SP: Junqueira \& Marin.

Martins, M. F. A., Debortoli, J. A. O., Teixeira, M. S., \& Arruda, E. A. (2009). A centralidade da infância no centro da cidade de Belo Horizonte: estudo sobre os usos e apropriações dos 
espaços no centro de Belo Horizonte [Trabalho completo]. In $12^{\circ}$ Encuentro de Geógrafos de América Latina (pp. 1-12). Montevideo: EGAL. Acesso em 25 de abril de 2013 , em http://egal2009.easyplanners.info/area05/

Patto, M. H. S. (1983). Da psicologia do 'desprivilegiado' à psicologia do oprimido. In M. H. S. Patto (Org.), Introdução à Psicologia Escolar (pp. 208-230). São Paulo: Queiroz.

Pereira, R. M. R., Cerdeira, A., Andreiuolo, B., \& Souza, S. J. (2005). Ladrões de sonhos e sabonetes: sobre os modos de subjetivação da infância na cultura do consumo. In S. J. Souza (Org.), Subjetividade em questão: a infância como crítica da cultura (pp. 99-116). Rio de Janeiro: 7 Letras.

Pérez, B. C., Póvoa, J., Monteiro, R., \& Castro, L. R. (2008). Cidadania e participação social: um estudo com crianças no Rio de Janeiro. Psicologia \& Sociedade, 20(2), 31-41.

Oliveira, S. B. C. \& Castro, L. R. (2009). Pesquisa-intervenção: nas malhas do desconhecido - Uma experiência de transicionalidade no espaço escolar. Psicologia Clínica, 21(2), 451-470.

Rua, M. A. (2007). Infância em territórios de pobreza: os falares e sentires das crianças. In V. M. R Vasconcellos \& M. J. Sarmento (Orgs.), Infância (in)visivel (pp. 205-242). Araraquara, SP: Junqueira \& Marin.

Sarmento, M. J. (2007). Visibilidade social e estudo da infância. In V. M. R Vasconcellos \& M. J. Sarmento (Orgs.), Infância (in) visivel (pp. 25-52). Araraquara, SP: Junqueira \& Marin.

Sarmento, M. J., Fernandes, N., \& Tomás, C. (2007). Políticas públicas e participação infantil. Educação, Sociedade e Culturas, 25, 183-206.

Simmel, G. (2005). As grandes cidades e a vida do espírito. Mana: Estudos de Antropologia Social, 11(2), 577-591.
Tuan, Yi-Fu. (1983). Espaço e Lugar. São Paulo: Difel.

Winnicott, D. W. (1975). O brincar e a realidade. Rio de Janeiro: Imago.

\section{Agradecimento}

Às agências de fomento - Fundação Bernard van Leer e CAPES - bolsa D. S.

Submissão em: 25/04/2013

Revisão em: 06/05/2013

Aceite em: 28/09/2014

Beatriz Corsino Pérez é mestre em Psicologia pela Universidade Federal do Rio de Janeiro. Doutora em Psicologia pela Universidade Federal do Rio de Janeiro.

E-mail: biacorsino@gmail.com

Marina Dantas Jardim é graduada em Psicologia pela Universidade Federal do Rio de Janeiro. Mestranda do Programa de Pós-graduação em Psicologia da UFRJ e bolsista CAPES. E-mail: mdantasjardim@gmail.com 